\title{
PENGARUH TIPE KEPRIBADIAN (THINKING DAN INTUITING) TERHADAP MINAT DAN HASIL BELAJAR BAHASA INDONESIA SISWA KELAS XI SMA CAHAYA MEDAN 2019/2020
}

\author{
Losten Tamba ${ }^{1}$, Berta Mariani Tarigan ${ }^{2}$ \\ Universitas Katolik Santo Thomas Medan, losten_tamba@ust.ac.id
}

\begin{abstract}
ABSTRAK
Penelitian ini bertujuan untuk mendeskripsikan pengaruh tipe kepribadian terhadap minat dan hasil belajar bahasa Indonesia kelas XI SMA Cahaya Medan tahun pembelajaran 2018/2019. Metode penelitian ini penelitian survei. Populasi dalam penelitian berjumlah 115 orang dengan purposive sampling sebanyak 60 siswa. Instrumen yang digunakan dalam penelitian ini adalah angket dan studi dokumentasi. Berdasarkan hasil penelitian ini ditemukan ditemukan bahwa ada pengaruh yang positif antara tipe kepribadian dan minat terhadap hasil belajar Bahasa Indonesia Kelas XI SMA Cahaya Medan. Implikasi penelitian ini adalah minat belajar yang besar dapat menimbulkan hasil belajar yang tinggi, demikian sebaliknya. Hal ini mengandung implikasi bahwa tipe kepribadian dan minat belajar mempunyai peran penting untuk meningkatkan hasil belajar.
\end{abstract}

\section{Kata Kunci : Tipe Kepribadian (Thinking dan Intuiting), Minat dan Hasil}

\begin{abstract}
ABSRACT
This study aims to describe the influence of personality types on the interest and learning outcomes of Indonesian students in class XI of Light Medan in the 2018/2019 academic year. The research method is survey research. The population in the study amounted to 115 people with purposive sampling of 60 students. The instruments used in this research were questionnaire and documentation study. Based on the results of this study, it was found that there was a positive influence between personality types and interests in the learning outcomes of Indonesian Language Class XI, SMA Medan. The implication of this study is that great learning interest can lead to high learning outcomes, and vice versa. This implies that the personality type and interest in learning have an important role to improve learning outcomes.
\end{abstract}

\section{Keywords: Personality Type (Thinking and Intuiting), Interests and Results}

\section{PENDAHULUAN}

Bahasa adalah manusiawi; bahasa penanda kemanusiaan. Artinya, di mana ada bahasa, di situ ada manusia. Setiap manusia, sebagai makhluk berpikir, yang memiliki organ alat ucap yang baik, akan dapat menggunakan bahasa sebagai alat komunikasi antar manusia. Bahasa itu dikuasai dengan proses belajar langsung dan tidak langsung, baik dalam keluarga maupun secara formal dalam pendidikan.

Bahasa sangat penting dalam kehidupan. Sebagai makhluk berpikir, bahasa digunakan sebagai alat berpikir.
Bukan hanya itu, bahasa merupakan gambaran hasil berpikir. Dengan bahasa, kemampuan berpikir manusia akan semakin berkembang. Bahasa juga sebagai sarana komunikasi. Bahasa dapat digunakan sebagai sarana untuk mengkomunikasikan pengalaman, perasaan, hasil berpikir, keinginan, dan banyak hal lain kepada orang lain. Kemampuan menggunakan bahasa juga dapat membuat orang dapat bersosialisasi dan beradaptasi dengan orang lain. Penggunaan bahasa juga dapat mempengaruhi orang lain untuk melakukan tindakan tertentu. 
Dengan pentingnya bahasa dalam kehidupan, membuat bahasa itu dipelajari atau diajarkan secara terpogram dalam pendidikan formal, informal, dan nonformal. Bahasa bukan hanya diajarkan dalam keluarga, namun juga diajarkan dalam pendidikan formal (pendidikan dasar sampai perguruan tinggi) dan dalam pendidikan nonformal seperti kursus-kursus. Hasil dari pembelajaran bahasa itu, membuat pembelajar mampu menangkap gagasan secara langsung atau tidak langsung dengan baik, benar, dan lengkap baik secara lisan maupun tertulis. Selain itu, hasil belajar bahasa itu juga berdampak pada kemampuan menyampaikan gagasan secara lisan dan tertulis dalam berbagai fungsi penggunaan bahasa.

Karena bahasa itu penting dalam kehidupan manusia sebagai alat komunikasi dan dalam konteks politis yaitu membangun persatuan dan kesatuan bangsa, bahasa Indonesia dijadikan sebagai pembelajaran wajib mulai dari pendidikan dasar sampai pendidikan tinggi. Keterampilan dalam menggunakan bahasa secara lisan maupun tertulis diharapkan dapat semakin meningkatkan rasa persatuan dan kesatuan bangsa Indonesia yang masyarakatnya majemuk dari segi latar belakang budaya. Karena itu, bahasa Indonesia dijadikan sebagai matapelajaran wajib di setiap jenjang pendidikan di Indonesia.

Sekalipun pembelajaran bahasa Indonesia sudah lama menjadi matapelajaran wajib, hasilnya seperti kurang maksimal. Banyak siswa/mahasiswa yang kurang mampu mendengarkan atau kurang mempunyai minat membaca. Pemahaman pembelajar rendah dalam mendengarkan seseorang dan membaca buku. Selain itu, banyak siswa/ mahasiswa yang kesulitan dalam menyampaikan gagasan, perasaan, atau hasil pemikirannya pada saat berbicara secara formal misalnya dalam diskusi, pidato, kata sambutan, presentasi, dan aktivitas berbicara yang lain. Hal yang lebih parah lagi adalah minimnya tulisan yang dapat dibuat oleh pembelajar bahasa Indonesia.
Dalam banyak hal, pembelajaran merupakan hal yang kompleks. Artinya, banyak hal yang harus diperhatikan dan yang mempengaruhi hasil belajar bahasa Indonesia, baik secara internal maupun secara eksternal. Secara internal misalnya tingkat intelektual, minat, tipe kepribadian, dan bakat. Unsur eksternal misalnya aspek yang mempengaruhi pembelajar dari luar, misalnya lingkungan belajar berupa trend, motivasi orang tua, kesuksesan seseorang yang dijadikan inspirasi, kebutuhan masyarakat, dan lain-lain. Karena itu, penelitian ini mengkaji masalah minat dan tipe kepribadian terhadap hasil belajar bahasa Indonesia. Tipe kepribadian yang diteliti hanya berkaitan dengan tipe thinking dan intuiting.

\section{LANDASAN TEORETIS}

1. Kepribadian

a. Konsep Kepribadian

Kepribadian berasal dari kata personality (bahasa Latin) yang berarti kedok atau topeng, yaitu tutup muka yang sering dipakai oleh pemain-pemain panggung, dengan tujuan menggambarkan perilaku, watak, atau pribadi seseorang. Secara filosofis dapat dikatakan bahwa pribadi adalah "aku yang sejati", sedangkan kepribadian merupakan "penampakan sang aku" dalam bentuk perilaku tertentu. Dari sini, muncul gagasan bahwa kepribadian adalah kesan yang diberikan seseorang kepada orang lain yang diperoleh dari sesuatu yang dipikirkan, dirasakan, diperbuat yang terungkap melalui perilaku seseorang. Para psikologi dan filsuf sepakat bahwa kepribadian dapat dilihat dari kenyataan yang bersifat biologis, kenyataan psikologis, dan kenyataan sosial.

Kepribadian menurut adalah semua corak perilaku dan kebiasaan individu yang terhimpun dalam dirinya dan digunakan untuk bereaksi serta menyesuaikan diri terhadap segala rangsangan baik dari luar maupun dari dalam (Koentjaraningrat, 2001: 87). Corak perilaku dan kebiasaan ini merupakan kesatuan fungsional yang khas pada seseorang. Perkembangan kepribadian 
tersebut bersifat dinamis, artinya selama individu masih bertambah pengetahuannya dan mau belajar serta menambah pengalaman dan keterampilan, mereka akan semakin matang dan mantap kepribadiannya. Kepribadian merupakan sifat hakiki individu yang tercermin pada sikap peserta didik. Keunikan tersebut tergantung pada tipe kepribadian mempengaruhi sikap dalam menyesuaikan diri dan bersosialisasi dengan lingkungan, termasuk dalam proses pembelajaran. Sikap terkadang didasari oleh emosi dan dorongan dari dalam diri, dengan dorongan yang baik maka akan menghasilkan sikap belajar yang baik pula atau dengan sebaliknya. Menurut Harton (2003: 22), kepribadian adalah keseluruhan sikap, perasaan, ekspresi, dan temperamen seseorang. Sikap, perasaan, ekspresi dan temperamen itu akan terwujud dalam tindakan dari seseorang bila dihadapkan pada situasi tertentu.

\section{b. Tipe Kepribadian}

Kepribadian manusia dapat dibagi menjadi dua tipe yaitu ekstraversi dan introversi (C.G Jung, 1971: 12). Orang yang ekstraversi dipengaruhi oleh dunia objektif yaitu dunia di luar dirinya. Orientasinya tertuju keluar: pikiran, perasaan, serta tindakan-tindakannya ditentukan oleh lingkungannya, baik lingkungan sosial maupun lingkungan nonsosial. Orang yang ekstraversi bersikap positif terhadap masyarakat, hatinya terbuka, mudah bergaul, hubungan dengan orang lain lancar. Orang yang introvert dipengaruhi oleh dunia subjektif, yaitu dunia di dalam dirinya sendiri. Orientasinya terutama tertuju ke dalam pikiran, perasaan, serta tindakantindakannya yang ditentukan oleh faktorfaktor subjektif. Penyesuaiannya dengan dunia luar kurang baik, jiwanya tertutup, sukar bergaul, sukar berhubungan dengan orang lain, kurang dapat menarik hati orang lain.

Kepribadian itu terdiri atas tiga sistem atau aspek yaitu: (a) das Es (the id), yaitu aspek biologi kepribadian adalah aspek yang orisinal. berfungsi dengan berpegang

ISSN : 15421-71667

Volume 3 Nomor 1, Juni 2020 kepada prinsip kenikmatan yaitu mencari keenakan dan menghindarkan diri dari ketidakenakan, (b) das Ich (the ego), yaitu aspek psikologi kepribadian yang timbul dari kebutuhan organisme untuk dapat berhubungan dengan dunia luar secara realistis. Tujuannya masih dalam garis kepentingan organisme, yaitu mendapatkan keenakan dan menghindarkan diri tetapi dalam bentuk dan cara yang sesuai dengan kondisi-kondisi dunia riil, sesuai dengan kenyataan baik itu kenyataan benda-benda maupun kenyataan nilai-nilai social, dan (c) das ueber ich atau aspek sosiologi kepribadian merupakan wakil nilai-nilai tradisional serta cita-cita masyarakat sebagaimana ditafsirkan orang tua kepada anak-anaknya yang diajarkan dengan berbagai perintah dan larangan (Freud (1998: 57).

Myers-Briggs (1998:

mengelompokkan kepribadian manusia berdasarkan pengembangan teori Carl Jung, yaitu:

\section{1) Sensing (Merasakan)}

Termasuk orang yang lebih suka menggunakan kekuatan otot dari pada otak. Lebih baik dia lemah fisik daripada pikiran. Kebanyakan dari mereka adalah atlet. Mereka sangat suka berolah raga. Dalam bercita-cita, orang sensing ini mengejar harta. Mereka sangat senang bila di kemudian hari bisa mewujudkannya. Beberapa kebiasaan orang yang memiliki mesin kecerdasan sensing yaitu berpijak pada yang nyata dan actual, faktual dan memperhatikan detil, menguraikan peristiwa secara urut, menyesuaikan kesempatan untuk praktik, pola bicara yang jelas dan teratur, pikiran yang terangkai satu dengan diikuti yang lainnya, berpikir linear, menggunakan fakta dan contoh yang jelas, tertarik pada pekerjaan yang membutuhkan kepraktisan, memasukkan detail dan fakta, dan mengingat masa lalu yang akurat.

\section{2) Thinking (Berpikir)}

Dalam pengertian thinking tipenya sudah sangat jelas, orang thinking sangat suka berpikir. Dalam menyelesaikan masalah mereka lebih senang menggunakan 
logika/pikirannya daripada sekedar menggunakan otot seperti yang dilakukan orang-orang sensing. Orang thinking ini benar-benar berpikir secara sistematis, apaapa berdasarkan teori. Beberapa kebiasaan orang yang memiliki kecerdasan thinking yaitu lebih menggunakan pikiran, memecahkan masalah secara logis, melakukan analisis tanpa mempertimbangkan pribadi, menghargai sesuatu yang masuk akal, adil, keputusannya didasarkan pada kriteria yang objektif, menjaga jarak dengan orang lain, berargumen dan berdebat sebagai panggilan kritis, jarang bertanya bila waktu kurang memungkinkan, dan percaya diri.

Aktivitas intelektual logika dapat memproduksi serangkaian ide yang disebut dengan berpikir. Jenis-jenis thinking dapat dikatakan extrovert atau introvert bergantung pada sikap seseorang. Orangorang yang memiliki karakteristik berpikir extrovert sangat tergantung pada pemikiran yang nyata, tetapi mereka juga menggunakan ide abstrak jika ide tersebut dapat ditransmisikan kepada mereka secara langsung, contohnya dari guru atau orang tua. Ahli matematika dan Insinyur menggunakan tipe pemikiran seperti ini. Demikian pula dengan akuntan karena mereka harus sangat objektif tergolong produktif. Tanpa interpretasi dari beberapa individu, ide dapat dikatakan fakta tanpa keaslian atau kreativitas (Jung, 1921: 31).

Orang-orang yang memiliki karakteristik berpikir introvert bereaksi terhadap rangsangan eksternal, tetapi interprestasi mereka terhadap suatu kejadian lebih diwarnai oleh pemaknaan internal yang mereka bawa dalam dirinya sendiri dibanding dengan fakta objektif yang ada. Penemu dan filsuf adalah contoh profesi yang menggunakan cara berpikir introvert karena mereka bereaksi terhadap dunia eksternal dalam sikap yang sangat subjektif juga kreatif dan menginterprestasikan data lama dengan cara yang baru. Saat mereka terbawa dalam situasi yang ekstrim, mereka akan terbawa dalam pemikiran mistis yang tidak produktif dan sangat individualistis

ISSN : 15421-71667

Volume 3 Nomor 1, Juni 2020 sehingga mereka menjadi tidak berguna bagi orang lain.

\section{3) Intuiting (Intuisi/Gerak Hati)}

Intuiting ini biasanya adalah orangorang yang sangat senang berimajinasi dan berfantasi. Mereka hidup dalam khayalan mereka. Mereka juga termasuk orang-orang yang pandai merangkai kata-kata indah. Beberapa kebiasaan orang yang memiliki kecerdasan intuiting yaitu mengolah informasi berdasarkan intuisi, lebih berminat pada pemahaman imajinatif, abstrak dan teoritis, mengandalkan inspirasi, memiliki pikiran yang berputar namun terpola, memberi ruang alternatif dan tidak lelah menyimpulkan, tertarik pada pekerjaan yang melibatkan kreativitas, menyukai cerita fiksi, berbicara hanya hal-hal besar dan strategis, dan cenderung untuk menyelesaikan kalimat orang lain.

Intuiting adalah kepribadian yang didominasi oleh otak kanan. Mereka adalah orang-orang yang punya kelebihan, yaitu kre atif. Mereka adalah orang yang suka berimprovisasi. Ituiting ini dibagi lagi menjadi dua yaitu introvert dan extrovert. Intuiting Introvert merupakan tipe pribadian yang selalu berpikiran positif. Mereka memiliki privasi yang kuat, tidak 'ember', namun mereka juga menyenangkan dijadikan sebagai mitra bisnis. Jenis kepribadian ini super keras kepala, meskipun demikian mereka terbuka untuk berbeda pendapat. Mereka sangat romantis, lucunya mereka juga anak mami'. Kepercayaan dirinya sangat kuat bahkan sering berlebihan. Mereka sering dieluelukan sebagai pahlawan bagi sekitarnya. Jika diibaratkan sebagai kendaraan, mereka adalah jenis kendaraan tanpa rem. Ketika sudah mentok tidak berhasil mencapai tujuannya, mereka langsung down. Sayangnya untuk memulihkan dari downnya ini tidak mudah, karena mereka baru menabrakkan kendaraannya tanpa rem.

Mereka juga pandai membuat intisari, selain juga menyukai hal-hal detil-detil yang estetik. Bahkan mereka pandai menampilkan diri secara atraktif. Letak kehebatannya adalah pada kemampuannya membuat 
konsep dan begitu perfeksionis ketika mereka menjalani konsepnya. Jika perlu mereka bersedia untuk turun tangan meskipun mereka konseptornya. Akhirnya orang lain menganggap mereka ini lengkap mulai dari mengonsep hingga detail pelaksanaan.

Intuiting Extrovert merupakan tipe kepribadian seperti detektif. Mereka mampu menemukan mana rangkaian peristiwa yang terputus dan merangkainya secara imaginer. Mereka tidak mau terlalu jauh berkenalan dengan orang lain, karena takut terbebani dengan hubungan yang lebih mendalam. Mereka memberikan standar yang tinggi bagi dirinya untuk menjalankan misi pribadinya meskipun kerap kali di beberapa area masih ada kurang seksama penanganannya. Kepribadiannya aktif dan tidak ketinggalan zaman, meskipun juga sesekali lari dari dunia realitas dan menjadi orang yang religius. Kehebatannya adalah ruang kreativitasnya yang luas, namun mereka juga tetaplah memerlukan pesta pelampiasan dengan berhurahura bersama teman-teman semisinya. Jika sedang mengejar misi, mereka mampu hidup terasing berpisah dari identitasnya sendiri. Pemikirannya sistemik, walaupun secara pribadi mereka mengabaikan orang lain. Sungguh pandai mengidentifikasi masalah ataupun

membuat program, namun tidak betah berla ma-lama.

\section{4) Feeling (Perasaan)}

Feeling adalah orang yang sangat penuh perasaan, selalu memikirkan perasaan orang lain, dan mudah simpati bila melihat orang lain kesusahan. Orang dengan tipe ini juga termasuk orang yang pandai berpenampilan. Bagi mereka penampilan adalah nomor satu. Kesan pertama yang muncul dan lawan jenis adalah penting bagi mereka. Mereka akan mulai gelisah ketika orang lain mulai berkomentar tentang penampilan mereka yang mungkin dianggap kurang bagus. Orang feeling ini biasanya orangnya modis. Pandai dalam mendekorasi tempat. Beberapa kebiasaan orang yang memiliki kecerdasan feeling yaitu lebih menggunakan kebiasaan, ingin menyenangkan orang lain, ingin selalu memimpin, menghargai perasaan orang lain, mengambil keputusan dengan mempertimbangkan akibat orang lain, bekerjasama di komunitas sosial yang baik, menghindari argumen, konflik dan komunikasi, perasaan mereka mudah sakit dan dendam, mampu menunjukkan kekaguman dan emosional, dan menggunakan banyak kata-kata berharga.

\section{5) Insting (Naluri)}

Orang instinct termasuk orang yang paling bisa jadi penengah. Dalam suatu pertengkaran, dia lebih memilih untuk tidak memihak salah satu di antaranya, walaupun terkadang ia mengetahui mana yang salah dan tidak. Orang dengan tipe ini adalah orang yang suka berkorban, cepat marah, tapi juga cepat sekali menjadi baik, bahkan menjadi lebih baik dari sebelumnya. Jelas juga bahwa orang instinct ini tidak punya penjelasan bahwa orang instinct ini tidak punya kekurangan, dia pun bahkan tidak punya kelebihan. Mereka yang tergolong instinct, cara kerja otaknya adalah seluruhnya. Jadi mereka sering kali berpikir secara lama, karena mereka selalu mempertimbangkan segala sesuatunya dari berbagai sesi. Tipe instinct adalah "The most wanted person" atau sulit ditemukan. Orang instinct ini kekurangannya adalah dia tidak bisa fokus dalam memiliki sebuah keahlian. Yang dicari orang instinct ini hanya kebahagiaan. Intinya orang instinct ini adalah orang yang tidak suka macammacam.

Beberapa kebiasaan orang yang memiliki kecerdasan instinct yaitu bereaksi secara spontan, mengolah informasi menggunakan naluri, mengingat hal-hal yang berkesan, orientasi pada mencari kebahagiaan, menyukai kebahagiaan untuk berperan serta, pikiran sederhana, polos, dan tidak aneh-aneh, keterampilan serba-serbi, menyukai pekerjaan siap menolong orang, dan tidak suka konflik.

\section{Minat}

a. Konsep Minat 
Minat adalah suatu rasa lebih suka dan rasa keterikatan pada suatu hal atau aktivitas, tanpa ada yang menyuruh. Minat pada dasarnya adalah penerimaan akan suatu hubungan antara diri sendiri dengan sesuatu di luar diri. Suatu minat dapat diekspresikan melalui suatu pernyataan yang menunjukkan bahwa siswa lebih menyukai suatu hal daripada hal lainnya, dapat pula dimanifulasikan melalui partisipasi dalam suatu aktivitas.

Mengembangkan minat terhadap suatu pada dasarnya adalah membantu siswa melihat bagaimana hubungan antara materi yang diharapkan untuk dipelajari dengan dirinya sendiri sebagai individu. Proses ini menunjukkan pada siswa bagaimana pengetahuan atau kecakapan tertentu mempengaruhi dirinya, melayani tujuantujuannya, memuaskan kebutuhankebutuhannya. Menurut Hurlock (1999: 34) dalam buku Makmun Khairani minat merupakan sumber motivasi yang mendorong orang untuk melakukan apa yang mereka inginkan bila mereka bebas memilih. Menurut Sutjipto (2001: 27) dalam buku Makmun Khairani minat adalah kesadaran seseorang terhadap suatu objek, orang, masalah, atau situasi yang mempunyai kaitan dengan dirinya. Artinya, minat harus dipandang sebagai sesuatu yang sadar. Karenanya minat merupakan aspek psikologi seseorang untuk menaruh perhatian untuk menaruh perhatian yang tinggi terhadap kegiatan tertentu dan mendorong yang bersangkutan untuk melaksanakan kegiatan tersebut.

Dari berbagai pengertian para ahli di atas dapat disimpulkan minat belajar adalah suatu perhatian, keinginan yang bersifat aktif sebagai landasan yang mendorong siswa dalam belajar tanpa ada paksaan dari pihak manapun dan merasa senang dalam mempelajari dalam melakukan kegiatan tersebut.

\section{b. Ciri dan Indikator Minat Belajar}

Minat anak dapat timbul dari berbagai sumber antara lain perkembangan insting dan hasrat, fungsi-fungsi intelektual, pengaruh lingkungan, pengalaman, kebiasaan, pendidikan, dan sebagainya. Guru harus mengetahui ciri-ciri minat yang ada pada siswa, guru dapat membedakan mana siswa yang berminat dalam belajar dan mana siswa yang tidak berminat dalam belajar, adapun ciri-ciri minat belajar menurut Susanto (2013: 62) adalah keputusan diambil dengan mempertahankan seluruh kepribadian, tergantung pada kegiatan belajar, sifatnya irasional, berlaku perseorangan dan pada suatu situasi, melakukan sesuatu terbit dari lubuk hati, melaksanakan sesuatu tanpa ada paksaan, melakukan sesuatu dengan senang hati, tumbuh bersama dengan perkembangan fisik dan mental, tergantung pada kegiatan belajar, melakukan sesuatu terbit dari lubuk hati, dan adanya rasa suka dan senang pada sesuatu yang diminati.

$\begin{array}{rrr}\text { Menurut Djamarah (2002: } & 132) \text {, } \\ \text { indikator minat belajar yaitu rasa }\end{array}$ suka/senang, pernyataan lebih menyukai adanya rasa keterkaitan adanya kesadaran untuk belajar tanpa disuruh, berpartisipasi dalam aktivitas belajar memberikan perhatian. Berbeda dengan Djamarah, Slameto (2010: 180) mengatakan beberapa indikator minat belajar yaitu perasaan senang, keterlibatan siswa, ketertarikan, dan perhatian siswa.

\section{Belajar}

\section{a. Konsep Belajar}

Belajar bukanlah sekedar mengumpulkan pengetahuan, tetapi belajar juga proses mental yang terjadi dalam diri seseorang yang menyebabkan perubahan perilaku. Belajar adalah suatu proses yang kompleks yang terjadi pada diri setiap orang sepanjang hidupnya. Proses belajar itu karena adanya interaksi antara seseorang dengan lingkungannya. Oleh karena itu, belajar dapat terjadi kapan saja dan di mana saja. Salah satu pertanda bahwa seseorang itu mungkin disebabkan oleh terjadinya perubahan pada tingkat pengetahuan, keterampilan atau sikap.

Belajar pada hakikatnya adalah proses interaksi terhadap semua interaksi terhadap semua situasi yang ada di sekitar 
individu. Belajar juga merupakan proses melihat, mengamati dan memahami sesuatu. Dengan begitu belajar dapat dipandang sebagai proses yang diarahkan kepada tujuan dan proses dibuat melalui berbagai pengalaman. Belajar merupakan proses kegiatan melihat, mengamati dan memahami sesuatu untuk memperoleh perubahan tingkah laku.

Ciri-ciri belajar adalah sebagai berikut (a) adanya kemampuan baru atau perubahan. Perubahan tingkah laku bersifat pengetahuan, keterampilan maupun nilai dan sikap, (b) perubahan itu tidak berlangsung sesaat saja melainkan menetap atau dapat disimpan, (c) perubahan itu tidak terjadi begitu saja melainkan harus dengan usaha. Perubahan terjadi akibat interaksi dengan lingkungan, (d) perubahan tidak sematamata disebabkan oleh pertumbuhan fisik/kedewasaan, tidak karena kelelahan.

\section{b. Hasil Belajar}

Secara etimologis, hasil belajar merupakan gabungan dari kata hasil dan belajar. (Kridalaksana, 1990: 14). Hasil adalah sesuatu yang diadakan (dibuat, dijadikan) akibat usaha. Belajar adalah berusaha memperoleh kepandaian atau ilmu untuk merubah tingkah laku atau tanggapan yang disebabkan pengalaman. Berdasarkan pengertian di atas maka dapat diperoleh suatu pengertian bahwa hasil belajar adalah kemampuan yang dimiliki oleh siswa setelah belajar, yang wujudnya berupa kemampuan kognitif, afektif, dan psikomotor yang disebabkan oleh pengalaman. Hasil belajar adalah pola-pola perbuatan, nilai-nilai, pengertian-pengertian, sikap-sikap, apresiasi dan keterampilan. Merujuk pemikiran Gagne, Supriono (2009: 33), hasil belajar itu berupa:

1) Informasi verbal yang kapabilitas mengungkapkan pengetahuan dalam bentuk bahasa, baik lisan maupun tertulis. Kemampuan merespons secara spesifik terhadap rangsangan spesifik. Kemampuan tersebut tidak memerlukan manipulasi simbol, pemecahan masalah maupun penerapan aturan.
2) Keterampilan intelektual yaitu kemampuan mempresentasikan konsep dan lambang. Kemampuan intelektual terdiri dari kemampuan mengategorisasi, kemampuan analitis sintesis fakta-konsep dan mengembangkan prinsip-prinsip keilmuan. Keterampilan intelektual merupakan kemampuan melakukan aktivitas kognitif bersifat khas.

3) Strategi kognitif yaitu kecakapan menyalurkan dan mengarahkan aktifitas kognitifnya sendiri. Kemampuan ini meliputi penggunaan konsep dan kaidah dalam memecahkan masalah.

4) Keterampilan motorik yaitu kemampuan melakukan serangkaian gerak jasmani dalam urusan dan koordinasi, sehingga terwujud otomatisme gerak jasmani.

5) Sikap adalah kemampuan menerima atau menolak objek berdasarkan penilaian terhadap objek tersebut. Sikap berupa kemampuan menginternalisasi dan eksternalisasi nilai-nilai. Sikap merupakan kemampuan menjadikan nilai-nilai sebagai standar perilaku.

\section{c. Hakikat Pembelajaran Bahasa dan Sastra Indonesia}

Pembelajaran bahasa Indonesia bertujuan agar pembelajaran dapat menggunakan bahasa Indonesia secara lisan dan tertulis dalam berbagai fungsi bahasa bahasa sesuai dengan situasi dan konteks. Dengan belajar bahasa diharapkan, siswa/ mahasiswa dapat memiliki keterampilan dalam menggunakan bahasa. Keterampilan terdiri dari empat yaitu terampil mendengarkan, terampil berbicara, terampil membaca, dan terampil menulis. Karena itu, bahan atau materi pembelajaran yang ada dalam matapelajaran bahasa Indonesia, misalnya materi pembajaran lisan (mendengarkan pembicaraan secara lansung, atau melalui rekaman/video), berbicara dalam situasi formal (misalnya menyampaikan kata sambutan, pidato, ceramah, presentasi), materi membaca (dengan berbagai jenis teks seperti puisi, cerita, karangan ilmiah, berita, dll.), dan menulis (misalnya menulis hasil 
pengalaman/ pengamatan, sastra, surat, berbagai tulisan ilmiah seperti esai, editoeial, makalah, laporan penelitian, dll.).

\section{KERANGKA BERPIKIR}

\section{Pengaruh Tipe Kepribadian Thinking terhadap Minat Belajar}

Minat belajar merupakan hal yang sangat penting dalam kegiatan pembelajaran, karena tinggi atau rendahnya minat akan mempengaruhi hasil belajar siswa. Indikator minat belajar: perasaan senang, keterlibatan siswa, ketertarikan, perhatian siswa. Fungsi minat belajar: minat memudahkan terciptanya konsentrasi, minat mencegah gangguan perhatian di luar, minat memperkuat melekatnya bahan pelajaran dalam ingatan, minat memperkecil kebosanan belajar dari diri sendiri. Pengaruh tipe kepribadian thinking terhadap minat belajar merupakan aktivitas psikologis siswa yang menunjukkan kecenderungan untuk menyukai atau menyenangi sesuatu. Dengan demikian, siswa yang memiliki minat belajar yang baik, diasumsikan ia akan belajar dengan sungguh-sungguh dengan tidak merasa terpaksa atau tertekan. Hal ini berarti semakin tinggi minat siswa dalam belajar, maka diharapkan siswa akan melaksanakan aktivitas pembelajaran yang maksimal sehingga akan menunjang hasil belajar lebih baik.

\section{Pengaruh Tipe Kepribadian Thinking terhadap Hasil Belajar}

Hasil belajar siswa adalah hasil usaha dalam rangka mengubah tingkah laku untuk mencapai tujuan yang diinginkan ditandai dengan tingginya hasil belajar yang diperoleh. Guru yang menguasai keterampilan mengajar dengan baik diduga dapat mengatasi kesulitan-kesulitan siswa dalam memahami materi pelajaran yang disampaikan oleh guru. Usaha untuk mencapai hasil belajar dari proses pembelajaran seorang siswa dipengaruhi oleh faktor internal dan eksternal. Faktor internal yang timbul dari dalam diri siswa itu sendiri, faktor eksternal yang berasal dari luar diri siswa itu sendiri. Sebagian besar mempunyai $I Q$ yang bagus, sangat cocok masuk sekolah unggulan. Kunci sukses tipe thinking adalah pandai membuat skala prioritas. Tipe thinking ini amat dominan otak kirinya. Mereka adalah orang yang pandai. Mereka mampu berpikir secara analitis dengan tingkat akurasi yang tinggi dan mampu bekerja dengan baik akan dapat mencapai hasil belajar yang tinggi.

\section{Pengaruh Tipe Kepribadian Thinking dan Minat belajar terhadap Hasil Belajar \\ Hasil belajar dipengaruhi oleh} kemampuan berpikir (intelektual) seseroang. Kemampaun berpikir adalah kemampuan menghubung-hubungkan sesuai hal untuk menghasilkan sesuatu atau memecahkan permasalahan. Selain kemampuan berpikir, hasil belajar juga dipengaruhi oleh minat terhadap sesuatu. Jika seseorang mempunyai keinginan dan kemauan dalam mempelajari sesuatu, maka hal itu akan meningkatkan kualitas hasil belajar.

\section{Pengaruh Tipe Kepribadian Intuiting terhadap Minat Belajar}

Kepribadiannya seperti detektif. Mereka mampu menemukan mana rangkaian peristiwa yang terputus dan merangkainya secara imaginer. Mereka tidak mau terlalu jauh berkenalan dengan orang lain, karena takut terbebani dengan hubungan yang lebih mendalam. Mereka memberikan standar yang tinggi bagi dirinya untuk menjalankan misi pribadinya meskipun kerap kali di beberapa area masih ada kurang seksama penanganannya. Dalam proses belajar, tipe intuiting selalu berfokus untuk memahami konsep. Upaya memahami konsep tersebut tidak mudah, maka tipe ini perlu dibantu dengan ilustrasi, grafis, dan film, yang akan memudahkan baginya untuk memahami konsep dari setiap pelajaran. Selain itu, proses belajar dari tipe ini juga dapat ditransfer dari bahasa tubuh si pengajar. Tipe intuiting akan menyukai dosen atau guru yang ekspresif dalam berkomunikasi baik dari aspek konten pilihan kata ataupun dari cara penyampaiannya. Konten pelajaran yang 
disukai tipe ini adalah konten yang dapat menggugah keingintahuan atau memberi inspirasi baru baginya. Tipe ini juga menyukai cerita-cerita petualangan yang fiktif karena hal itu akan membuka cakrawala fantasinya. Pemberian motivasi bagi tipe Intuiting cukup dengan ditantang melihat masa depan yang 1 ebih baik. Tipe intuiting memiliki optimisme yang kuat dan juga keras kepala untuk memperjuangkan kemauannya. Dengan memvisualkan tentang masa depannya, maka akan lebih mudah bagi tipe ini untuk membangun sendiri route keberhasilannya. Demikian pula dalam kegiatan belajar, tipe ini akan lahap membaca buku jika sudah melihat manfaat bagi dirinya.

\section{Pengaruh Tipe Kepribadian Intuiting terhadap Hasil Belajar}

Intuiting ini biasanya adalah orangorang yang sangat senang berimajinasi dan berfantasi. Intuiting termasuk orang yang sangat penuh perasaan, selalu memikirkan perasaan orang lain dan mudah iba bila melihat orang lain kesusahan. Sedangkan dalam suatu pertengkaran dia lebih memilih untuk tidak memihak salah satu di antaranya, walaupun terkadang ia mengetahui mana yang salah dan tidak. Jadi dapat di simpulkan bahwa tipe Intuiting sangat mempengaruhi hasil belajar siswa karena dari tipe tersebut kita dapat melihat seberapa jauh hasil yang di peroleh dalam meningkatkan hasil belajar siswa.

\section{Pengaruh Tipe Kepribadian Intuiting serta Minat Belajar terhadap Hasil Belajar}

Dalam proses belajar, tipe intuiting selalu berfokus untuk memahami konsep. Upaya memahami konsep tersebut tidak mudah, maka tipe ini perlu dibantu dengan ilustrasi, grafis, dan film, yang akan memudahkan baginya untuk memahami konsep dari setiap pelajaran. Selain itu, proses belajar dari tipe ini juga dapat ditransfer dari bahasa tubuh si pengajar. Tipe intuiting akan menyukai dosen atau guru yang ekspresif dalam berkomunikasi baik ISSN : 15421-71667

Volume 3 Nomor 1, Juni 2020 dari aspek konten pilihan kata ataupun dari cara penyampaiannya. Konten pelajaran yang disukai tipe ini adalah konten yang dapat menggugah keingintahuan atau memberi inspirasi baru baginya. Tipe ini juga menyukai cerita-cerita petualangan yang fiktif karena hal itu akan membuka cakrawala fantasinya. Pemberian motivasi bagi tipe intuiting cukup dengan ditantang $\mathrm{m}$ elihat masa depan yang lebih baik. Tipe intui ting memiliki optimisme yang kuat dan juga keras kepala untuk memperjuangkan kemauannya. Dengan memvisualkan tentang masa depannya, maka akan lebih mudah bagi tipe ini untuk membangun sendiri route keberhasilannya. Demikian pula dalam kegiatan belajar, tipe ini akan lahap membaca buku jika sudah melihat manfaat bagi dirinya.

\subsection{Perumusan Hipotesis}

Terdapat pengaruh yang signifikan antara tipe kepribadian (thinking dan intuiting) dan minat terhadap hasil belajar siswa pada mata pelajaran bahasa Indonesia Kelas XI SMA Cahaya Medan tahun pelajaran 2018/2019.

\section{METODE PENELITIAN}

Pendekatan penelitian ini adalah pendekatan penelitian kuantitatif. Metode yang digunakan pada penelitian ini adalah metode deskriptif survei. Metode deskriptif survei adalah pengumpulan data primer dengan memberikan pertanyaan-pertanyaan kepada responden individu. Penelitian ini dilaksanakan di SMA Cahaya Jalan Hayam Uruk No.11 Medan.Penelitian ini dilakukan pada semester ganjil tahun pelajaran 2018/2019. Desain penelitian yang digunakan pada penelitian ini adalah desain penelitian kuantitatif untuk studi evaluatif. Populasi dalam penelitian ini adalah seluruh siswa kelas XI SMA Cahaya Medan. Dalam penelitian ini teknik yang digunakan dalam pengumpulan data yaitu dengan observasi, angket, dan dokumentasi. Pengujian hipotesis dilakukan dengan uji korelasi dan uji regresi.

\section{A. Hasil Penelitian dan Pembahasan}




\section{Pengaruh Tipe Kepribadian Thinking terhadap Minat Belajar Siswa}

Tabel 1. Hasil analisis regresi tipe kepribadian thinking terhadap minat belajar

\begin{tabular}{|c|c|c|c|c|c|c|}
\hline Sumber & Koef & $\mathrm{R}$ & $\mathrm{r} 2$ & Thitung & Sig & Keterangan \\
\hline \multirow{2}{*}{$\begin{array}{c}\text { konstanta tipe } \\
\text { kepribadian thinking }\end{array}$} & 91,301 & & & & & \multirow[b]{2}{*}{$\begin{array}{c}\text { positif } \\
\text { signifikan }\end{array}$} \\
\hline &, 856 & $0,099 \mathrm{a}$ & ,010 & 2,571 & 0.02 & \\
\hline & & & & $n g$ & & \\
\hline
\end{tabular}

Berdasarkan tabel korelasi (R) sebesar 0,099 menunjukkan bahwa ada hubungan positif variabel $(\mathrm{X})$ dengan variable $(\mathrm{Y})$. Nilai r2 sebesar0,010 menunjukkan bahwa variabel tipe kepribadian memberikan pengaruh sebesar $1 \%$ terhadap variabel minat belajar. Signifikansi nilai korelasi (r) diketahui dengan melihat kolom $\mathrm{t}$ dan sig. Nilai thitung sebesar 2,571 lebih besar dari ttabel (> ttabel 2,011) dan sig.0,02(<0,05) lebih kecil dari taraf signifikansi $1 \%$, sehingga dapat diartikan bahwa nilai korelasi (r) antara tipe kepribadian terhadap minat belajar adalah signifikan. Berdasarkan uraian di atas, disimpulkan bahwa tipe kepribadian (X) mempunyai pengaruh positif dan signifikan terhadap minat belajar. Selanjutnya, dirumuskan persamaan regresi antara penggunaan variabel tipe kepribadian thinking dan minat belajar sebagai berikut: $\mathrm{Y}$ $=91,301+0,856 \mathrm{X}$ Persamaan tersebut menunjukkan bahwa nilai konstanta (a) sebesar 91,301dan nilai koefisien (b) minat belajar sebesar 0,856 yang berarti sebelum dikenai variabel bebas (X) minat belajar siswa sebesar 91,301 setelah dikenai variabel bebas $(\mathrm{X})$, minat belajar siswa meningkat 0,856 poin.

\section{Pengaruh Kepribadian Thinking terhadap Hasil Belajar}

Hasil analisis regresi tipe kepribadian thinking terhadap hasil belajar:

\begin{tabular}{|c|c|c|c|c|c|c|}
\hline $\begin{array}{c}\text { Sumb } \\
\text { er }\end{array}$ & $\begin{array}{c}\text { Ko } \\
\text { ef }\end{array}$ & R & r2 & $\begin{array}{c}\text { Thit } \\
\text { ung }\end{array}$ & $\begin{array}{c}\text { Si } \\
\mathrm{g}\end{array}$ & $\begin{array}{c}\text { Keter } \\
\text { angan }\end{array}$ \\
\hline $\begin{array}{c}\text { konsta } \\
\text { nta }\end{array}$ & $\begin{array}{c}75, \\
523\end{array}$ & & & & & \\
$\begin{array}{c}\text { tipe } \\
\text { keprib } \\
\text { adian } \\
\text { thinki }\end{array}$ & 0,4 & 0,0 & 0,0 & 2,33 & 0,0 & $\begin{array}{c} \\
\text { positif } \\
\text { signifi } \\
\text { kan }\end{array}$ \\
\hline
\end{tabular}

Berdasarkan nilai korelasi (R) sebesar 0,58 menunjukkan bahwa ada hubungan positif variabel $(\mathrm{X})$ dengan variable $(\mathrm{Y})$. Nilai r2 sebesar0,003menunjukkan bahwa variabel tipe kepribadian thinking memberikan pengaruh sebesar $0,3 \%$ terhadap variabel hasil belajar. Signifikansi nilai korelasi (r) diketahui dengan melihat kolom $t$ dan sig. Nilai thitung sebesar 2,335lebih besar dari ttabel (> ttabel 2,011) dan sig.0,02 (< $0,05)$ lebih kecil dari taraf signifikansi $0,3 \%$, sehingga dapat diartikan bahwa nilai korelasi (r) antara tipe kepribadian thinking terhadap hasil belajar adalah signifikan. Berdasarkan uraian di atas, disimpulkan bahwa tipe kepribadian thinking mempunyai pengaruh positif dan signifikan terhadap hasil belajar(Y). Selanjutnya, dirumuskan persamaan regresi antara penggunaan variabel tipe kepribadian thinking dan hasil belajar (Y) sebagai berikut: Y77,523+0,467X. Persamaan tersebut menunjukkan bahwa nilai konstanta (a) sebesar77,523dan nilai koefisien (b) hasil belajar sebesar 0,467 yang berarti sebelum dikenai variabel bebas (X) tipe kepribadian thinking siswa sebesar 77,523 setelah dikenai variabel bebas $(\mathrm{X})$, hasil belajar siswa meningkat 0,467 poin.

2. Pengaruh Tipe Kepribadian Thinking dan Minat Belajar terhadap Hasil Belajar

\section{Hasil Analisis Regresi Berganda Tipe} Kepribadian Thinking dan Minat Belajar terhadap Hasil Belajar Berdasarkan nilai konstanta adalah 64,618 , tipe kepribadian thinking $(0,346)$ 
dan minat belajar $(0,141) . \quad Y=$ $64,618+0,346+0,141$ Menyatakan bahwa jika nilai variabel bebas $\mathrm{X}=0$ maka nilai Y adalah 64,618. Dalam kata lain bahwa nilai hasil belajar tanpa tipe kepribadian thinking dan minat belajar adalah 64,618. Koefisien regresi variabel tipe kepribadian thinking sebesar 0,346 artinya bahwa peningkatan satu unit variabel tipe kepribadian thinking dengan asumsi variabel bebas lain konstanta akan menyebabkan kenaikan hasil belajar sebesar 0,346. Koefisien regresi variabel minat belajar atau sebesar 0,141 artinya bahwa peningkatan satu unit variabel minat belajar dengan asumsi variabel bebas lainnya konstanta akan menyebabkan kenaikan hasil belajar sebesar 0,141 .

\section{Pengaruh Tipe Kepribadian Intuiting terhadap Minat Belajar}

Hasil analisis regresi tipe kepribadian intuiting terhadap minat belajar

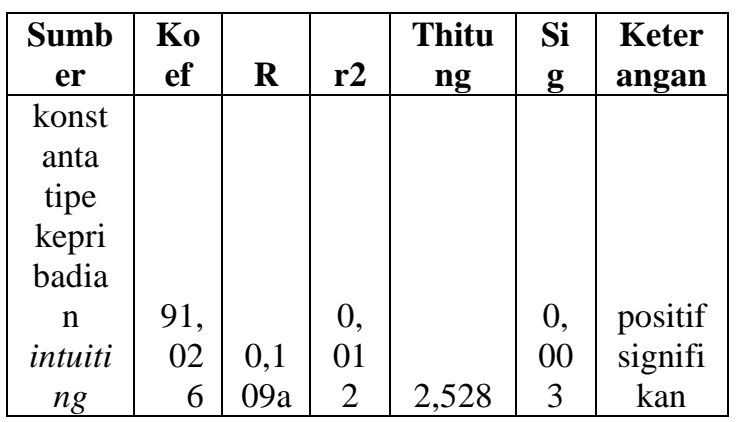

Berdasarkan tabel di atas nilai korelasi (R) sebesar 0,109a menunjukkan bahwa ada hubungan positif variabel $(\mathrm{X})$ dengan variable (Y). Nilai r2 sebesar0,003 menunjukkan bahwa variabel tipe kepribadian intuiting memberikan pengaruh sebesar 1,2\% terhadap variabel hasil belajar. Signifikansi nilai korelasi (r) diketahui dengan melihat kolom t dan sig. Nilai thitung sebesar 2,528 lebih besar dari ttabel (> ttabel 2,060) dan sig.0,02 (< $0,05)$ lebih kecil dari taraf signifikansi $1,2 \%$, sehingga dapat diartikan bahwa nilai korelasi (r) antara tipe kepribadian intuiting terhadap hasil belajar adalah signifikan. Berdasarkan uraian di atas, disimpulkan bahwa tipe kepribadian intuiting mempunyai pengaruh positif dan signifikan terhadap hasil belajar. Selanjutnya, dirumuskan persamaan regresi antara penggunaan variabel tipe kepribadian intuiting dan hasil belajar sebagai berikut: $Y \quad 91,026+0,859 \quad \mathrm{X}$ Persamaan tersebut menunjukkan bahwa nilai konstanta (a) sebesar91,026 dan nilai koefisien (b) hasil belajar sebesar 0,859 yang berarti sebelum dikenai variabel bebas (X) tipe kepribadian intuiting siswa sebesar 91,026 setelah dikenai variabel bebas hasil belajar siswa meningkat 0,859 poin.

\section{Pengaruh Tipe Kepribadian Intuiting terhadap Hasil Belajar}

Tabel 2. Hasil analisis regresi tipe kepribadian intuiting terhadap hasil belajar:

\begin{tabular}{|c|c|c|c|c|c|c|}
\hline Sumber & Koef & R & r2 & Thitung & Sig & Keterangan \\
\hline $\begin{array}{c}\text { konstanta tipe } \\
\text { kepribadian intuiting }\end{array}$ & 76,564 & & & & & \\
\cline { 2 - 7 } & 0,603 & $0,098 \mathrm{a}$ & 0,010 & 2,474 & 0,040 & $\begin{array}{c}\text { positif } \\
\text { signifikan }\end{array}$ \\
\hline
\end{tabular}

Berdasarkan tabel di atas nilai korelasi (R) sebesar 0,098a menunjukkan bahwa ada hubungan positif variabel (X) dengan variable (Y). Nilai $\mathrm{r} 2$ sebesar 0,003 menunjukkan bahwa variabel tipe kepribadian intuiting memberikan pengaruh sebesar $1, \%$ terhadap variabel hasil belajar. Signifikansi nilai korelasi (r) diketahui dengan melihat kolom $\mathrm{t}$ dan sig. Nilai $\mathrm{t}$ hitung sebesar 2,474 lebih besar dari ttabel (> ttabel 2,060) dan sig.0,02 $(<0,05)$ lebih kecil dari taraf signifikansi $1, \%$, sehingga dapat diartikan bahwa nilai korelasi (r) antara tipe kepribadian intuiting terhadap hasil belajar adalah signifikan. Berdasarkan uraian di atas, disimpulkan bahwa tipe 
kepribadian intuiting mempunyai pengaruh positif dan signifikan terhadap hasil belajar. Selanjutnya, persamaan regresi antara penggunaan variabel tipe kepribadian intuiting dan hasil belajar Y 76,564 +0,603 $X$. Persamaan ini menunjukkan bahwa nilai konstanta (a) sebesar76,564 dan nilai koefisien (b) hasil belajar sebesar 0,603 yang berarti sebelum dikenai variabel bebas (X) tipe kepribadian intuiting siswa sebesar 91,026 setelah dikenai variabel bebas hasil belajar siswa meningkat 0,603 poin.

\section{Pengaruh Tipe Kepribadian Intuiting dan Minat Belajar terhadap Hasil Belajar}

Hasil analisis regresi tipe kepribadian intuiting dan minat belajar terhadap hasil belajar:

Nilai konstanta adalah 43,643 tipe kepribadian intuiting $(0,913)$ dan minat belajar $(0,362)$. Persamaan regresi $\mathrm{Y}=$ $43,643+0,913+0,362$ menyatakan bahwa jika nilai variabel bebas $\mathrm{X}$ maka nilai Y adalah 43,643. Dalam kata lain, nilai hasil belajar tanpa tipe kepribadian intuiting dan minat belajar adalah 43,643

Koefisien regresi variabel tipe kepribadian intuiting sebesar 0,913artinya bahwa peningkatan satu unit variabel tipe kepribadian intuiting dengan asumsi variabel bebas lain konstanta akan menyebabkan kenaikan hasil belajar sebesar 0,362. Koefisien regresi variabel minat belajar atau sebesar 0,913 artinya bahwa peningkatan satu unit variabel minat belajar dengan asumsi variabel bebas lainnya konstanta akan menyebabkan kenaikan hasil belajar sebesar 0,913

7. Perbandingan Tipe Kepribadian Thinking, Intuiting serta Minat Belajar terhadap Hasil Belajar

Hasil pengujian hipotesis menunjukkan bahwa hasil belajar siswa SMA Cahaya Medan semester ganjil menunjukkan bahwa tipe kepribadian yang unggul didominasi oleh siswa yang berkepribadian tipe intuiting begitu juga dengan minat belajar. Siswa yang berkepribadian tipe intuiting mendapatkan pengaruh sebesar 0,913 dan minat belajar sebesar 0,362 dan hasil belajarnya 43,643

\section{KESIMPULAN}

1. Siswa dengan tipe kepribadian thinking memiliki minat belajar yang tinggi.

2. Tipe kepribadian thinking sangat berpengaruh terhadap hasil belajar bahasa Indonesia.

3. Minat belajar siswa bertipe kepribadian dikategorikan sangat baik tinggi.

4. Ada korelasi signifikan antara tipe kepribadian intuiting terhadap hasil belajar bahasa Indonesia.

5. Ada pengaruh pengaruh tipe kepribadian intuiting dan minat belajar terhadap hasil belajar bahasa Indonesia.

6. Tipe kepribagian (thinking dan intuiting) dan minat berpengaruh terhadap hasil belajar bahasa Indonesia.

\section{DAFTAR PUSTAKA}

Arifin, Zainal. Evaluasi Instruksional: Prinsip-Teknik-Prosedur, Bandung: Remaja Rosdakarya, 2011

Bugin, Burhan. 2014. Metodologi Penelitian Kuantitatif. Bandung: Kencana Prenada Media.

Hamalik, Oemar. 2014. Kurikulum dan Pembelajaran. Jakarta: Bumi Aksara.

Jess Feist \& Gregory J. Feist. Teori Kepribadian. Jakarta: Rineka Cipta.

Khairani, Makmun. 2013. Psikologi Belajar. Yogyakarta: CV Aswaja Pressindo.

Khairin \& Danim Sudarwan. 2014. Psikologi Pendidikan (Perspektif Baru). Bandung: Alfabeta.

Mustaqim. 2012. Psikologi Pendidikan. Yogyakarta: Pustaka Pelajar. 
Purwanto. 2009. Evaluasi Hasil Belajar. Yogyakarta: Pustaka Pelajar.

Rusdiana. 2015. Pengelolaan Pendidikan. Bandung: CV Pustaka Setia.

Slameto. 2003. Belajar dan Faktor-faktor yang Mempengaruhinya. Rev. Jakarta: PT Rineka Cipta.

Sudjana. 2005. Metode Statistika. Bandung: Tarsito

Sugiyono. 2010. Metode Penelitian Pendidikan Pendekatan Kuantitatif, Kualitatif dan R\&D. Bandung: Alfabeta.

Suharsimi, Arikunto. 2009. Dasar-Dasar Evaluasi Pendidikan. Jakarta: Bumi Aksara. 2017. Prosedur Penelitian Suatu Pendekatan Praktik. Rev. Jakarta: Rineka Cipta.

Sugandi, A. 2004. Teori Pembelajaran. Semarang: UPT UNNES Press.

Supriyono. 2009. Cooperative Learning Teori dan Aplikasi. Yogyakarta: Pustaka Pelajar.

Suprijanto.2012. Pendidikan Orang Dewasa. Bandung: Bumi Aksara.

Suryosubroto. 2010. Proses Belajar Mengajar di Sekolah. Jakarta: Rineka Cipta.

Syah, Muhibbin. 2015. Psikologi Pendidikan. Bandung: PT Remaja Rosdakarya.

Ujam Jaenudin. 2018. Tipe Kepribadian. Yogyakarta: DIVA Pres 